The patients' reason for non-vaccination was registered if applicable. Patients were classified as vaccinated according to the EULAR recommendations if they had a yearly influenza, an every-five-year pneumococcal and a decennial tetanus toxoid vaccine, the latter as recommended in the general population.

\begin{tabular}{|c|c|c|c|c|c|c|}
\hline & & $\begin{array}{c}\text { All AllRD } \\
\text { patients }(n=633)\end{array}$ & $\mathrm{RA}(\mathrm{n}=489)$ & PSA (n=73) & AS (n=58) & JIA (n=13) \\
\hline \multirow{3}{*}{ Influenza vaccine n(\%) } & Yes & $438(69.2)$ & $360(73.6)$ & $45(61.6)$ & $28(48.3)$ & $5(38.5)$ \\
\hline & No & $195(30.8)$ & $129(26.4)$ & $28(38.4)$ & $30(51.7)$ & $8(61.5)$ \\
\hline & Unk & $0(0)$ & $0(0)$ & $0(0)$ & $0(0)$ & $0(0)$ \\
\hline \multirow{3}{*}{ Pneumococcal vaccine $n(\%)$} & Yes & $203(32.1)$ & $174(35.6)$ & $19(26.0)$ & $10(17.2)$ & $0(0)$ \\
\hline & No & $352(55.6)$ & $259(53.0)$ & $45(61.6)$ & $39(67.2)$ & $9(69.2)$ \\
\hline & Unk & $78(12.3)$ & $56(11.5)$ & $9(12.3)$ & $9(15.5)$ & $4(30.8)$ \\
\hline \multirow{3}{*}{ Tetanus toxoid vaccine $n(\%)$} & Yes & $348(55.0)$ & $265(54.2)$ & $41(56.2)$ & $33(56.9)$ & $9(69.2)$ \\
\hline & No & $174(27.5)$ & $139(28.4)$ & $21(28.8)$ & $12(20.7)$ & $2(15.4)$ \\
\hline & Unk & $111(17.5)$ & $85(17.4)$ & $11(15.1)$ & $13(22.4)$ & $2(15.4)$ \\
\hline \multirow{3}{*}{$\begin{array}{l}\text { Compliant with EULAR } \\
\text { recommendations n(\%) }\end{array}$} & Yes & $117(18.5)$ & $100(20.4)$ & $9(12.3)$ & $8(13.8)$ & $0(0)$ \\
\hline & No & $429(67.8)$ & $318(65.0)$ & $55(75.3)$ & $45(77.6)$ & $11(84.6)$ \\
\hline & Unk & $87(13.7)$ & $71(14.5)$ & $9(12.3)$ & $5(8.6)$ & $2(15.4)$ \\
\hline \multirow{3}{*}{ Hepatitis B vaccine $n(\%)$} & Yes & $193(30.5)$ & $138(28.2)$ & $20(27.4)$ & $28(48.3)$ & $7(53.8)$ \\
\hline & No & $339(53.6)$ & $289(59.1)$ & $31(42.5)$ & $15(25.9)$ & $4(30.8)$ \\
\hline & Unk & $101(16.0)$ & $62(12.7)$ & $22(30.1)$ & $15(25.9)$ & $2(15.4)$ \\
\hline \multirow{3}{*}{$\begin{array}{l}\text { History of Varicella zoster } \\
\text { virus n(\%) }\end{array}$} & Yes & $447(70.6)$ & $355(72.6)$ & $47(64.4)$ & $34(58.6)$ & $11(84.6)$ \\
\hline & No & $58(9.2)$ & $46(9.4)$ & $3(4.1)$ & $8(13.8)$ & $1(7.7)$ \\
\hline & Unk & $128(20.2)$ & $88(18.0)$ & $23(31.5)$ & $16(27.6)$ & $1(7.7)$ \\
\hline
\end{tabular}

Results: The vaccination status of 633 consecutive patients was obtained. The group consisted of $489(77.2 \%)$ patients with RA, 73 (11.5\%) patients with PsA, 58 (9.2\%) patients with AS and $13(2.1 \%)$ patients with JIA with a mean \pm standard deviation age of $59.8 \pm 13.6,55.8 \pm$ $13.5,45.2 \pm 14.0$ and $35.0 \pm 13.9$ respectively. Of all included patients with AIIRD, $69.2 \%$ were vaccinated for influenza, followed by vaccination rates of $55.0 \%, 32.1 \%$ and $30.5 \%$ for tetanus toxoid, pneumococcal and hepatitis B vaccination, respectively (Table 1). In addition, 70.6\% of patients with AIIRD had a history of varicella zoster virus infection. Various reasons for non-vaccination were reported, of which 'No specific reason' was the most common, closely followed by non-awareness of the need for pneumococcal vaccination. The compliance with EULAR recommendations was $18.5 \%$. Of the 429 patients with AlIRD not vaccinated according to the EULAR recommendations, 68 (15.9\%) patients were not compliant with all three of the vaccines, 136 (31.7\%) were not compliant with 2 vaccines (1: pneumococcal and 2: influenza or tetanus toxoid vaccine), 148 (34.5\%) were not compliant with 1 vaccine (103 pneumococcal, 41 tetanus toxoid and 4 influenza vaccine) and 77 (17.9\%) patients were unaware of their vaccination status for at least 1 vaccine.

Conclusion: In our patients with AIIRD, the highest vaccination rate for recommended vaccines was observed for influenza (nearly 70\%). Not being vaccinated for pneumococcus was the main reason why patients did not comply with the EULAR recommendations. More attention is needed to determine and optimise the vaccination status of AIIRD patients and to increase the awareness regarding the pneumococcal vaccine.

Disclosure of Interests: : Delphine Bertrand: None declared, Sofie Coenen: None declared, Sofia Pazmino: None declared, Veerle Stouten: None declared, Diederik De Cock: None declared, Kristien Van der Elst: None declared, Rene Westhovens Grant/research support from: BristolMyers Squibb, Consultant for: Celltrion, Galapagos-Gilead, Marc Ferrante Grant/research support from: Janssen, Pfizer, Takeda, Consultant for: Abbvie, Boehringer-Ingelheim, Ferring, Janssen, Mitsubishi Tanabe, Takeda, MSD, Pfizer, Speakers bureau: Abbvie, Boehringer-Ingelheim, Chiesi, Ferring, Janssen, Lamepro, Mitsubishi Tanabe, MSD, Pfizer, Takeda, Tramedico, Tillotts, Zeria, Patrick Verschueren Grant/research support from: Unrestricted Pfizer Grant for Early RA research DOI: 10.1136/annrheumdis-2019-eular.3060

\section{THU0628 IMMUNE-RELATED ADVERSE EVENTS INDUCED BY CANCER IMMUNOTHERAPIES. BIG DATA ANALYSIS OF 13,051 CASES (IMMUNOCANCER INTERNATIONAL REGISTRY)}

Manuel Ramos-Casals ${ }^{1}$, Oliver Lambotte ${ }^{2}$, Marie Kostine ${ }^{3}$, Leonard Calabrese ${ }^{4}$, Maria Suarez-Almazor ${ }^{5}$, Clifton Bingham ${ }^{6}$, Timothy R. Radstake ${ }^{7}$, Chiara Baldini ${ }^{8}$, Thierry Schaeverbeke ${ }^{9}$, Jacques-Eric Gottenberg ${ }^{10}$, Hendrik Schulze-Koops ${ }^{11}$, Jan Leipe ${ }^{12}$, Cassandra Calabrese ${ }^{4}$, Pilar Brito-Zerón ${ }^{13}$, Alejandra FloresChávez $^{14}$, Belchin Kostov ${ }^{15}$, Soledad Retamozo ${ }^{16}$, Gustavo Citera ${ }^{17}$, Eva Aguilar ${ }^{18}$, Michael Richter ${ }^{19}$, Merav Lidar ${ }^{20}$, Benjamin Fisher ${ }^{21}$, JeanMarie Michot ${ }^{2}$, David Liew ${ }^{22}$, Russell Buchanan ${ }^{23}$, Marte Schrumpf-Heiberg ${ }^{24}$, Philippe Guilpain ${ }^{25}$, Debashish Danda ${ }^{26}$, Peter Olssonn ${ }^{27}$, Yasunori Suzuki ${ }^{28}$, Saadettin Kılıçkap ${ }^{29}$, Gabriela Hernandez-Molina ${ }^{30}$, Virginia Fernandes Moça Trevisani $^{31}$, Sonja Praprotnik ${ }^{32}$, Ildiko Fanny Horváth ${ }^{33}$, Naoto Azuma ${ }^{34}$, Berkan Armagan ${ }^{29}$, Munther Khamashta ${ }^{35}$, Xavier Mariette ${ }^{36} .{ }^{1} \mathrm{H}$. Clinic, IDIBAPS, Barcelona, Spain; ${ }^{2}$ Bicêtre Hosp, Paris, France, ${ }^{3}$ Centre Hosp Univ, Bordeaux, France; ${ }^{4}$ Cleveland Clinic Foundation, Cleveland, $\mathrm{OH}$, United States of America; ${ }^{5}$ Univ Texas MD Anderson Cancer Center, Houston, TX, United States of America; ${ }^{6}$ Johns Hopkins Univ, Baltimore, MD, United States of America; ${ }^{7}$ Univ Medical Center Utrecht, Utrecht, Netherlands; ${ }^{8}$ Pisa Univ, Pisa, Italy, ${ }^{9}$ Centre Hosp Univ, Bordeaux, France; ${ }^{10}$ Strasbourg Univ, CNRS, Strasbourg, France; ${ }^{11}$ Univ of Munich, Munich, Germany, ${ }^{12}$ Univ of Mannheim, Mannheim, Germany; ${ }^{13} \mathrm{H}$. CIMASanitas, Barcelona, Spain; ${ }^{14}$ Hosp de Especialidades, Mexico, Mexico; ${ }^{15}$ IDIBAPS Barcelona, Spain; ${ }^{16}$ INICSA-UNC-CONICET, IUCBC, Córdoba, Argentina; ${ }^{17}$ IREP, Buenos Aires, Argentina; ${ }^{18}$ GEAS-SEMI Spanish Registry, Madrid, Spain; ${ }^{19}$ Mayo School of Graduate Med Education, Rochester, United States of America; ${ }^{20}$ Sheba Med Center, Tel Aviv, Israel; ${ }^{21}$ Univ of Birmingham, Birmingham, United Kingdom;

${ }^{22}$ Aus-REISAMIC Registry, Victoria, Australia; ${ }^{23}$ Austin Health, Melbourne, Australia: ${ }^{24}$ Diakonhjemmet Hosp, Oslo, Norway, ${ }^{25}$ Montpellier Univ. Hosp, Montpellier, France; ${ }^{26}$ Christian Med College and Hosp, Vellore, India; ${ }^{27}$ Skåne Univ Hosp Malmö, Malmö, Sweden; ${ }^{28}$ Kanazawa Univ Hosp, Ishikawa, Japan; ${ }^{29}$ Hacettepe Univ, Ankara, Turkey, ${ }^{30}$ INCMNSZ, Mexico, Mexico; ${ }^{31}$ Federal Univ of São Paulo, São Paulo, Brazil; ${ }^{32}$ Univ Medical Centre, Ljubljana, Slovenia;

${ }^{33}$ Debrecen Univ, Debrecen, Hungary, ${ }^{34}$ Hyogo Coll Medicine, Nishinomiya, Japan; ${ }^{35}$ Dubai Hosp, UAE, Dubai, United Arab Emirates; ${ }^{36}$ Université Paris-Sud, Paris, France

Background: The ImmunoCancer International Registry (ICIR) is a Big Data-Sharing multidisciplinary network composed by 39 specialists in Rheumatology, Internal Medicine, Immunology and Oncology from 18 countries focused on immune-related adverse events (irAEs) related to cancer immunotherapies (Cls).

Objectives: To analyse the worldwide scenario of irAEs associated with the use of $\mathrm{Cls}$ in this Century.

Methods: The first objective of the ICIR has been the development of a systematic literature review crossing Cls terms with immune diseases defined according to MedDRAVR 15.0 .

Results: The cumulated number of cases per year of irAEs has increased exponentially, with 12,648 patients who developed 13,051 irAEs reported until Dec 31, 2018:

: Combined Cls were used in 1962 (16\%) patients, checkpoint inhibitors in 7099 (66\%, overwhelmingly CTLA4 and PD1 inhibitors) and Tyrosine Kinase inhibitors in $3327(31 \%)$; ipilimumab, nivolumab and pembrolizumab were associated with nearly $60 \%$ of reported cases. Organ-specific classification of irAEs is summarized in the figure:

The Top10 irAEs included enterocolitis $(18 \%)$, pneumonitis $(12 \%)$, thyroiditis $(11 \%)$, myocarditis $(6 \%)$, myositis $(5 \%)$, hypophysitis $(5 \%)$, hepatitis $(5 \%)$, neuropathy $(4 \%)$, adrenal $(3 \%)$ and joint involvement $(3 \%)$. Most irAEs are organ-specific symptoms not fulfilled criteria of systemic/rheumatic diseases.

Conclusion: More than 13,000 cases of irAEs triggered by Cls have been reported, with the organ-specific autoimmune damage of the endocrine, digestive and pulmonary systems accounting for $70 \%$ of the total reported irAEs. 


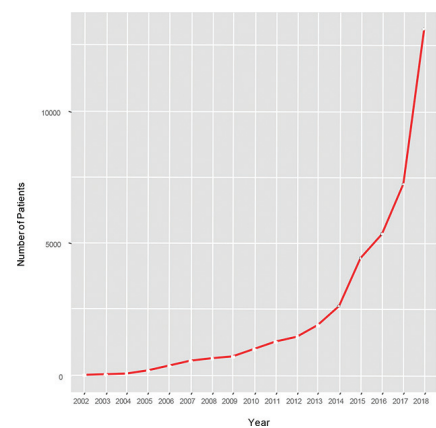

Organ-specific classification of irAEs (cases)

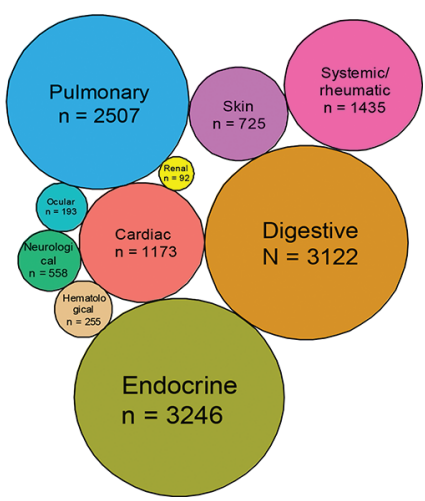

Disclosure of Interests: Manuel Ramos-Casals: None declared, Oliver Lambotte: None declared, Marie Kostine: None declared, Leonard Calabrese Consultant for: Bristol-Myers-Squibb, Genentech and Astra-Zeneca., Maria Suarez-Almazor : None declared, Clifton Bingham Grant/research support from: BMS, Consultant for: AbbVie, BMS, Eli Lilly, Genentech/ Roche, Janssen, Pfizer, Sanofi/Regeneron, Timothy R. Radstake: None declared, Chiara Baldini: None declared, Thierry Schaeverbeke: None declared, Jacques-Eric Gottenberg Grant/research support from: BristolMyers Squibb, Grant/research support from: Bristol-Myers Squibb, Consultant for: Bristol-Myers Squibb, Lilly, Pfizer, Sanofi-Genzyme, UCB Pharma, Consultant for: Bristol-Myers Squibb, Eli Lilly, UCB, Sanofi-Genzyme, Pfizer, Hendrik Schulze-Koops Grant/research support from: Novartis, Pfizer, Roche, Consultant for: Abbvie, Actelion, Amgen, AstraZeneca, Biogen International, BMS, Celgene, Chugai, GSK, Hospira, Janssen-Cilag, Leo Pharmaceuticals, Lilly, MSD, Medac, Merck, Novartis, Pfizer, Hexal Sandoz, Sanofi, Roche, UCB, Paid instructor for: Abbvie, Actelion, Amgen, AstraZeneca, Biogen International, BMS, Celgene, Chugai, GSK, Hospira, Janssen-Cilag, Leo Pharmaceuticals, Lilly, MSD, Medac, Merck, Novartis, Pfizer, Hexal Sandoz, Sanofi, Roche, UCB, Speakers bureau: Abbvie, Actelion, Amgen, AstraZeneca, Biogen International, BMS, Celgene, Chugai, GSK, Hospira, Janssen-Cilag, Leo Pharmaceuticals, Lilly, MSD, Medac, Merck, Novartis, Pfizer, Hexal Sandoz, Sanofi, Roche, UCB, Jan Leipe Grant/research support from: Novartis, Pfizer; Scientific Support: Novartis, Pfizer, Consultant for: AbbVie, AstraZeneca, BristolMyers Squibb, Celgene, Hospira, Janssen-Cilag, LEO Pharma, Lilly, Novartis, Roche, Sanofi, Speakers bureau: AbbVie, Bristol-Myers Squibb, Celgene, Janssen-Cilag, Lilly, Novartis, MSD, Pfizer, Roche, Sanofi, UCB, cassandra calabrese Speakers bureau: Regeneron/Sanofi, Pilar BritoZerón: None declared, Alejandra Flores-Chávez: None declared, Belchin Kostov: None declared, Soledad Retamozo: None declared, Gustavo Citera: None declared, Eva Aguilar: None declared, Michael Richter: None declared, Merav Lidar: None declared, Benjamin Fisher Consultant for: Novartis, Roche, Medlmmune, Bristol-Myers Squibb, Jean-Marie Michot: None declared, David Liew: None declared, Russell Buchanan: None declared, Marte Schrumpf-Heiberg: None declared, Philippe Guilpain: None declared, Debashish Danda: None declared, Peter Olsson: None declared, Yasunori Suzuki: None declared, Saadettin Kılıçkap: None declared, Gabriela Hernandez-Molina: None declared, Virginia Fernandes Moça Trevisani: None declared, Sonja Praprotnik: None declared, Ildiko Fanny Horváth: None declared, Naoto Azuma: None declared, Berkan Armagan: None declared, Munther Khamashta: None declared, Xavier Mariette
Grant/research support from: Servier, Consultant for: AstraZeneca, BristolMyers Squibb, GlaxoSmithKline, Janssen, Pfizer, UCB Pharma DOI: 10.1136/annrheumdis-2019-eular.2707

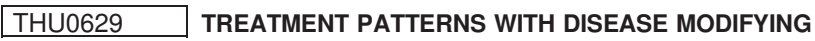 ANTI-RHEUMATIC DRUGS IN UNITED STATES VETERANS WITH NEWLY DIAGNOSED RHEUMATOID ARTHRITIS, PSORIATIC ARTHRITIS, OR ANKYLOSING SPONDYLITIS}

Jessica A. Walsh ${ }^{1}$, Shaobo Pei ${ }^{1}$, Gopi Penmetsa ${ }^{1}$, Brian Sauer ${ }^{1}$, Vikas Patil ${ }^{1}$, Jodi Walker $^{2}$, Jerry Clewell ${ }^{2}$, Kevin Douglas ${ }^{2}$, Daniel Clegg ${ }^{1}$, Grant Cannon ${ }^{1}$, Ahmad Halwani ${ }^{1} .{ }^{1}$ Salt Lake City Veteran Affairs and University of Utah Medical Centers, Salt Lake City, United States of America; ${ }^{2}$ AbbVie, Inc, North Chicago, United States of America

Background: Delays in treatment for inflammatory arthritis (IA) are associated with unfavorable outcomes, including impaired quality of life, irreversible joint damage, and disability.

Objectives: To characterize treatment initiation patterns in patients with newly diagnosed rheumatoid arthritis (RA), psoriatic arthritis (PsA), and ankylosing spondylitis (AS).

Methods: Incident IA cases were identified between January 1, 2007 and December 31, 2015, in patients enrolled in the Veteran Health Administration, using International Classification of Diseases codes and natural language processing. Patterns of treatment initiation and non-treatment with disease modifying anti-rheumatic drugs (DMARDs) were assessed in the 12-month follow-up period after the incident diagnosis.

Results: The population consisted of 12,118 IA patients $(9,711$ RA, 1,472 PsA, 935 AS), with $91.3 \%$ males and a mean age of 63.7. In total, $58.2 \%$ of patients initiated a DMARD within 12 months after diagnosis (RA $60.0 \%$, PsA $64.3 \%$, AS 29.6\%) (Figure). A DMARD was dispensed $\leq 30$ days after IA diagnosis in $41.2 \%$ of patients and $\leq 90$ days in $50.0 \%$ of patients. Rheumatology specialty care was accessed during the study period, prior to DMARD dispensation, by $82.7 \%$ of patients exposed to a non-biologic DMARD and $90.0 \%$ of patients exposed to a biologic DMARD. The percentage of IA patients with DMARD exposure during the 12-month follow-up period increased from $48.8 \%$ in 2008 to $66.4 \%$ in 2015 .

Figure. DMARD exposure patterns within 12 months after the initial diagnosis of inflammatory arthritis.
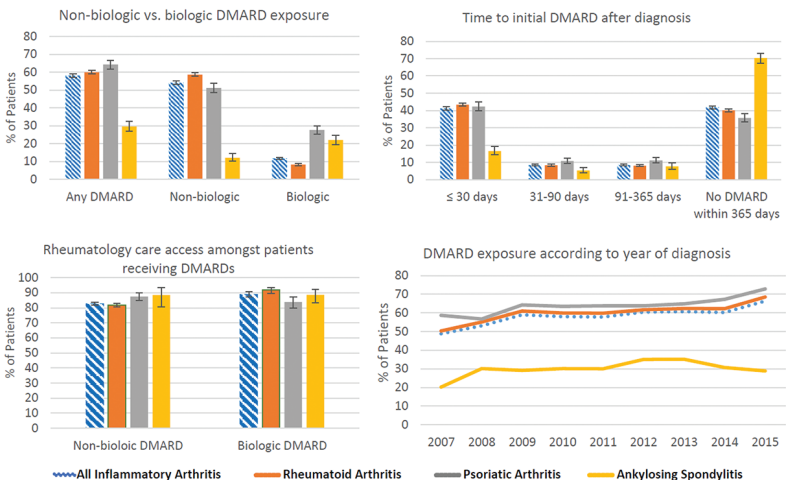

Conclusion: Approximately one-half of patients received treatment with a DMARD within 90 days after their initial IA diagnosis. DMARD treatment rates during the initial 12 months after diagnosis increased between 2007 and 2015, but non-treatment remained common, particularly in patients with AS. Timely access to a rheumatology provider is likely important for early DMARD treatment.

\section{REFERENCES:}

[1] $\mathrm{Ng}$, et al. BMJ Open. 3:e002468

Disclosure of Interests: Jessica A. Walsh Grant/research support from: Abbvie, Pfizer

, Consultant for: Abbvie, Celgene, Lilly, Novartis

Shaobo Pei: None declared, Gopi Penmetsa: None declared, Brian Sauer Grant/research support from: Amgen, Vikas Patil: None declared Jodi Walker Shareholder of: Abbvie, Employee of: Abbvie, Jerry Clewell Shareholder of: Abbvie, Employee of: Abbvie, Kevin Douglas Shareholder of: Abbvie, Employee of: Abbvie, Daniel Clegg Grant/research support from: Amgen grant, Grant Cannon Grant/research support from: Amgen 